\title{
Selvmordsatferd blant sammekjønnsseksuelle kvinner og menn: funn fra nyere representative studier
}

\author{
Ved Bera Ulstein Moseng
}

\section{Hvor stort er omfanget av psykisk uhelse og selvmordsatferd blant lesbiske og homofile? Hva er risiko- faktorer og beskyttende faktorer? I denne artikkelen vil vi ta for oss nyere forskningslitteratur på feltet.}

Det har i de senere årene kommet en rekke befolkningsbaserte representative studier som dokumenterer at lesbiske, bifile og homofile er mer plaget av psykiske vansker, rusproblemer og selvmordsatferd enn befolkningen generelt ${ }^{1)}$. Fram til begynnelsen av 1990-tallet var psykisk helse blant sammekjønnsseksuelle en ikke-problemstilling, det være seg blant forskere eller politikkutformere. Spфrsmål om sammekjønnsseksuell atferd eller seksuell orientering inngikk derfor ikke i statlige europeiske og nordamerikanske helseunders $\varnothing$ kelser.

Den første generasjonen med studier (1970-) måtte således basere seg på selekterte utvalg, dvs. de tok sitt utgangspunkt i homofile og lesbiske som lett lot seg rekruttere til denne type unders $\varnothing$ kelser fordi de var åpne om sin sammekjønnsseksuelle livsform, eller fordi de frekventerte lesbisk/homofile utesteder, var medlemmer av homoorganisasjoner etc.

Sammekjønnsseksuelle kvinner og menn utgjør en heterogen gruppering bestående av svært mange, ofte atskilte livsformer. I denne artikkelen brukes derfor begrepet sammekjønnsseksuell som en overordnet samlebetegnelse. Store deler av populasjonen lever eksempelvis skjult eller har lite eller ikke noe å gjøre med den såkalte gay-scenen i byene. En ikke ubetydelig andel kvinner og menn har sex med personer av samme kjønn, uten å forstå seg selv som lesbiske, bifile eller homofile.

Det er således et problem at noen forskere - men langt fra alle - har brukt eller fremdeles bruker denne type ikke-representative unders $\varnothing$ kelser til å si noe om risikoog selvmordsatferd i den sammekjønnsseksuelle populasjonen generelt (Moseng, 2005).

Siden siste halvdel av 1990-tallet har forskning på helseforhold blant sammekjønnsseksuelle kvinner og menn blitt tilf $\varnothing \mathrm{rt}$ betydelige forskningsmidler pga. den akselererende aids-epidemien i USA og Europa. Noen foregangsland, som USA, Canada, Nederland, New Zealand og Sverige (men ikke Norge), har valgt å inkludere spørsmål om seksuell atferd og orientering i de regulære nasjonale helseunders $\varnothing$ kelsene som en fors $\varnothing$ ksordning. Denne nye generasjonen representative, ofte befolkningsbaserte studier, dokumenterer en overrepresentasjon av angst- og depresjonssymptomer, samt selvmordstanker og selvmordsfors $\varnothing \mathrm{k}$ blant ikke-heteroseksuelle kvinner og menn. Liknende tendenser framgår også av NOVAs studie Levekår og livskvalitet blant lesbiske kvinner og homofile menn (Hegna et al., 1999), den representative befolkningsbaserte NOVA - unders $\varnothing \mathrm{kel}$ sen Ung i Norge 2002 (Hegna, 2007; Moseng, 2003) og NOVA-unders $\varnothing$ kelsen Ung i Oslo 2006 (Moseng, 2007). Disse studiene dokumenterer ikke bare en skjevfordeling av helse mellom lesbiske og homofile og den heteroseksuelle minoritetsbefolkningen, de antyder også skjevfordelinger innad i den sammekjønnsseksuelle populasjon. De kvinner og menn som utgjør den sammekjønnsseksuelle minoritet, tilhører ikke «automatisk» en høyrisikogruppe mht. å være plaget av psykiske vansker eller et alkohol- eller rusproblem. Lesbiske og homofile flest rapporterer om en meget god livskvalitet. Samtidig er det slik at en liten andel i eksempelvis NOVAs utvalg oppgir at de strever tungt med sine liv. Denne minoriteten er betydelig st $\varnothing$ rre enn den tilsvarende minoriteten blant heteroseksuelle kvinner og menn. Noen av de risikofaktorer og livsformer som kan forklare denne skjevfordelingen av psykisk helse, vil bli nærmere forklart nedenfor.

Sosial ulikhet i helse - minoritets- og majoritets-befolkningsproblematikk

Over hele den vestlige verden har nasjonale helse- og levekårsunders $\emptyset$ kelser de siste 30 årene dokumentert en påtakelig og vedvarende skjevfordelinger av helse mellom majoritets- og minoritetsbefolkninger. Innvandrere, funksjonshemmede og urbefolkninger som den samiske befolkningsminoriteten i Norge er gode eksempler på marginaliserte grupperinger som på denne måten er overrepresentert på den psykiske og somatiske uhelsestatistikken (for samer gjelder dette i hovedsak for dem som lever i geografiske områder hvor de er i et klart mindretall). På begynnelsen av 1990-tallet argumenterte fremtredende amerikanske epidemiologer for at det var rimelig at også minoriteten sammekjønnsseksuelle kvinner og menn burde behandles ut fra et slikt analytisk levekårsperspektiv. Ved å inkludere spørsmål om seksuell status i de regulære nasjonale levekårsunders $\varnothing$ kelsene, ble det på midten av 1990-tallet for første gang dokumentert at skjevfordelinger av helse innad i befolkninger - og som tradisjonelt er blitt forklart ved variabler som kjønn, etnisk opprinnelse, sosial status eller klasseforhold - også kan være et utslag av seksuell orientering eller et valg av en ikke-heteroseksuell samlivsform.

Det er imidlertid viktig å ikke overdrive denne tendensen til sosial ulikhet i helse mellom sammekjønnsseksuelle som minoritet og den heteroseksuelle majoritetsbefolkningen. Forskning og psykisk helseforebyggende arbeid blant lesbiske og homofile bør ta sitt utgangspunkt i at lesbiske og homofile flest har svært gode liv.

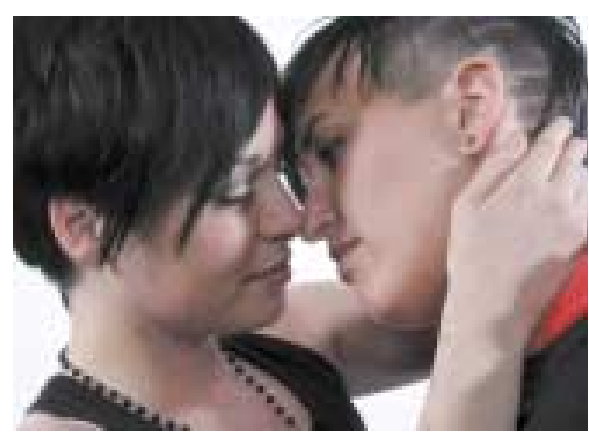

Foto: (c) Lill-Ann Chepstow-Lusty/Camilla/BONO 2007

\footnotetext{
1) Bagley og Tremblay 1997, Bontempo \& D'Augelli 2002, Burgard et al. 2005, Case et al. 2004, Cochran et al. 2000, Cochran \& Mays 2000, Cochran \& Mays 2000b, Cochran 2001, Cochran et al. 2003, Cochran et al. 2004, Corliss et al. 2006, Diamant et al. 2000, Drabble \& Trocki 2005, DuRant \& Krowchuck 1998, Faulkner \& Cranston 1998,

Fergusson et al. 1999, Garofalo et al. 1998 og 1999, Gilman et al. 2001, Gruskin et al. 2001, Halpern et al. 2004, Herrell et al. 1999, Mayes \& Cochran 2001, Mills et al. 2004,

Pathela et al. 2006, Paul et al. 2002, Remafedi et al. 1998, Remafedi 1999 og 1999b, Resnick et al. 1997, Robin et al. 2002, Roth et al. 2005, Russel et al. 2001, Russel et al. 2001b, Russel \& Joyner 2001, Russel et al. 2002, Russel 2003, Saewyc et al. 1999, Saewyc et al. 2006, Sandfort et al. 2001, Sandfort et al. 2006, Scheer et al. 2002, Scheer et al. 2003, Skegg et al. 2003, Smith et al. 1999, Trocki et al. 2005 og Valanis et al. 2000
} 
Det er imidlertid blitt dokumentert en overrepresentasjon av psykiske vansker, rusmisbruk og hiv/aids i målgruppen. Denne type skjevfordeling av hel se kan studeres epidemiologisk som sosial ulikhet i helse. I følge Verdens helseorganisasjon (W H O) er negativ systematisk forskjellsbehandling en av fem strukturelle samfunnsbetingel ser som kan generere statistiske skjevfordelinger av levekår- og helseproblemer innad i en befolkning: K vinner, urbefolkninger, ikke-vestlige innvandrere framheves gjerne som eksempler på minoritetsgrupper som på denne måten kan være negativt forfordelt. $\mathrm{N}$ år data fra U ng i N orge 2002 dokumenterer at unge sammekjønnsseksuelle kvinner og menn, på samme måte som ikke-vestlige innvandrere, funksjonshemmede eller den samiske urbefolkningen, kan være overrepresentert mht. å ha dårlige levekår og dårlig helse, er dette en indikasjon på at norsk samfunnsliv fortsatt er preget av et seksuelt verdihierarki. Selv blant unge lesbiske og homofile synes det å være forbundet betydelige psykososial e belastninger til det å praktisere en livsform som går på tversav den norske majoritetsbefolkningens verdihorisonter for hva som utgjør tidsriktige former for kjærlighet, samliv og seksualitet blant menn og kvinner.

\section{Diskriminering og psykisk helse} - forskjellsbehandling som risikofaktor

D et er flere grunner til at befolkningsminoriteten sammekjønnsseksuelle kvinner og menn kan ha dårlige levekår.

0 verrepresentasjonen av psykisk uhelse blant sammekjønnsseksuelle kan selvsagt begrunnes ut fra et særegent teologisk eller moralfilosofisk perspektiv ved at selvidentifiserende lesbiske og homofile per definisjon har dårligere naturlige forutsetninger enn selvidentifiserende heteroseksuelle for å leve harmoniske voksenliv. De har vanskeligere for å integrere seksualiteten på en fullgod måte i sin identitet/identitetsforståelse og i sitt samliv med andre. Er livsformen objektivt feil, vil nødvendigvis et sammekjønnsseksuelt kjærlighetsliv ofte munne ut i en form for psykisk og sosial ubalanse. M edfører ikke denne type essensialistiske forklaringer gyldighet, kan imidlertid svikt i sammekjønnsseksuelle kvinner og menns evne til å håndtere sine liv forklares sosiologisk, dvs. med utgangspunkt i hvordan det norske majori- tetssamfunnet de siste 100 - 150 årene har forholdt seg til sammekjønnsseksuelle som livsformsminoritet. H vor fritt har egentlig sammekjønnsseksuelle kvinner og menn stått i å praktisere en livsform som går på tvers av den norske majoritetsbefolkningens verdihorisonter mht. kjærlighet, samliv og seksualitet?

Forskning antyder at mange av de helseproblemene som sammekjønnsseksuelle strever med, ofte kan bunne i fordommer og negativ forskjellsbehandling - særlig i form av mobbing og trakassering (Bildt, 2004; Bontempo \& D 'A ugelli, 2002;

Corliss et al., 2002; Faulkner $\&$ C ranston, 1998; DuRant \& Krowchuck, 1998, $G$ arafalo et al., 1998; M ays \& Cochran, 2001; M oseng, 2005; Paul et al., 2002; Robin et al., 2002; Saewyc et al., 2006). $M$ ays $\&$ C ochrans studie $M$ ental $H$ ealth $C$ orrelates of Perceived Discrimination (2001) kopler skjevfordeling av helse til opplevd forskjellsbehandling pga. seksuell orientering. Det er derfor foruroligende å merke seg at representative befolkningsbaserte data fra U ng i N orge (N OVA) dokumenterer at norske ungdommer og tenåringer (12 - 18 år) har grunnleggende negative holdninger til homoseksualitet ( M oseng, 2003, 2005). På en vurderingsskala fra 1 til 10 - der 1 til 5 er å regne som en negativ vurdering og 6 til 10 som en positiv vurdering - blir elevene i U ng i N orge undersøkelsene bedt om å rangere ulike grupper av ungdommer. A v samtlige respondenter i N OVA s U ngdataundersøkelser 1994-2001, til sammen 25731 ungdommer, ga hele 42 prosent av el evene gruppen homoseksuelle ett poeng og kun fire prosent ga gruppen ti poeng.

Det er på bakgrunn av dette negative holdningsteppet man må forstå at lesbiske, bifile og homofile ungdom rapporterer om å være fem ganger mer utsatt for trusler og vold enn ungdom generelt (H egna et al., 1999; M ays \& C ohran, 2001; M oseng, 2005; R ussell \& Joiner, 2001). Dette framgår også av ferske representative U ng i O slo-data fra 2006 (M oseng, 2007). Internasjonale undersøkel ser antyder at lesbisk, bifil og homofil ungdom opplever skolen som en utrygg arena, de rapporterer om daglige verbale trakasserier og noen forteller også at de skulker skolen i et forsøk på å håndtere presset relatert til det å være en ikke-heterosek- suell elev. N OVA sholdningsundersøkelser gir ingen grunn til å tro at forholdene er særlig bedre på norske skoler. Ferske data dokumenterer at når unge homofile og lesbiske blir utsatt for vold, er voldsutøverne ofte jevnaldrende venner eller bekjente, som har banket dem opp (M oseng, 2007). Samtidig er unge homofile kvinner og menn skjevfordelt i forhold til unge heterofile mht. å være utsatt for emosjonell eller fysisk mishandling av sine foreldre, steforeldre etc. - mer enn to av ti oppgir å ha opplevd slike konflikter under oppveksten (Russell \& Joiner, 2001;

C orliss et al., 2002; M oseng, 2007).

Sett på bakgrunn av at rangering av og tilhørende negativ forskjellsbehandling av lesbiske og homofile livsformer framstår som en sentral risikofaktor mht. psykisk uhelse og selvmordsatferd, framstår antidiskrimineringstiltak i regi av majoritetssamfunnet som et tilsvarende beskyttende grep. Det å foregripe diskriminering av seksuelle minoriteter bør ikke være den enkelte lesbiske, bifile og homofiles ansvar. Å diskriminere eller marginalisere minoriteter, som innvandrere, funksjonshemmede eller lesbiske/ homofile, oppleves som en entydig negativ handling som få i det norske pluralistisk innstilte majoritetssamfunnet vil vedkjenne seg. Således svarer én av fire lesbiske og homofile i en svensk representativ arbeidslivsundersøkelse bekreftende på at det forekommer diskriminering av sammekjønnsseksuelle på arbeidsplassen, mens kun én av ti heterofile kvinner og menn gjorde det samme (Bildt, 2004; Ljunggren et al., 2003). En slik diskrepans sannsynliggjør at det i den heterofile majoritetsbefolkningen finner sted en diskré, men likefullt negativ rangering av sammekjønnsseksualitet som kjærlighets- og samlivsform. A lle skoleelever og arbeidstakere har imidlertid krav på å ha et skoleog arbeidsmiljø som er fritt for negativ forskjellsbehandling. For at dette skal finne sted er det nødvendig at det norske majoritetssamfunnet i form av arbeidsgivere, skoleledelse, fagforeninger etc. oppviser reell nulltoleran se overfor homofobe ytringer eller konkrete overgrep. Ved trakassering, mobbing eller sjikanering av lesbiske, bifile og homofile skoleel ever eller arbeidstakere må det gripes raskt inn. Slike markeringer fra arbeidsgiver/ 
skoleledelsens side vil forebygge negative mestringsstrategier blant lesbiske, bifile og homofile arbeidstakere og skoleelever, eksempelvis i form av tilbaketrekking fra arbeidet og skolen som sosialt fellesskap.

\section{Internalisert homofobi som risikofaktor}

Foreliggende forskning antyder at det er sammenhenger mellom eventuelle negative holdninger i den norske majoritetsbefolkningen og internalisert homofobi blant unge sammekjønnsseksuelle. Unge lesbiske og homofile som befinner seg i en tidlig identitetsskapende fase, er ofte sårbare. Mange er i begynnelsen av sine sammekjønnsseksuelle liv og er plaget av skam og identitetskonflikter med tanke på å leve ikke-heteroseksuelle liv. Den eksisterende forskningen antyder at når unge lesbiske og homofile strever med stigmatisering og internaliserte fordommer i form av negative selvbilder, mister de også evnen til å håndtere sine egne liv og sin egen helse, det være seg å praktisere sikrere sex eller å forholde seg på en konstruktiv måte til ulike former for rusmiddelproblematikk. Flere representative befolkningsbaserte unders $\varnothing$ kelser dokumenterer sammenhenger mellom selvmordsfors $\varnothing \mathrm{k}$ og det å ha vært utsatt for vold og trakassering blant selvidentifiserte homofile og lesbiske. Mange av disse strever med skam og identitetsproblematikk og negative selvbilder (Garofalo et al., 1998, 1999; Mays \& Cochran, 2001).

Forskningen antyder også at det er tenåringer og unge voksne som oppviser mest problemer mht. seksuell selvidentifikasjon. Det er blant de yngste man finner flest biseksuelle, eller tenåringer som ytrer ubehag i det å måtte forholde seg til seksuelle kategorier - da i særdeleshet til kategoriene kvinnelig og mannelig homoseksualitet. Et mindretall fortsetter å ha et trøblete forhold til seksuelle kategorier hele sitt sammekjønnsseksuelle liv, men for de fleste homofile og lesbiske faller seksualiteten ganske så udramatisk på plass et sted i tyve- eller trettiårene. Noe av overrepresentasjonen av psykiske vansker og selvmordsatferd blant sammekjønnsseksuelle kvinner og menn skyldes uten tvil denne type livsfasebetingede skamproblemer - og tilh ørende identitetsproblematikk.
Noen unge kvinner og menn som forelsker seg i personer av samme kjønn, synes eksempelvis å kompensere dette med å praktisere mye heterosex (Saewyc, 1999). I den vestlige verden har enkelte kristne organisasjoner fått mye negativ oppmerksomhet fordi de fors $\varnothing$ ker å reorientere sammekjønnselskende kvinner og menn "tilbake til" en antatt opprinnelig heterofil identitet. Det er i denne sammenheng verdt å merke seg at representative data antyder at en del sammekjønnsseksuelle bedriver en form for selvmedisinering de fors $\varnothing$ ker å "reorientere" seg selv. Kvinner og menn, som forstår seg selv som heterofile, mer enn 95 prosent av den norske befolkningen, har lite homosex (mindre enn 10 prosent har prøvd én gang). Lesbiske og homofile har på sin side mye sex på tvers av sin seksuelle selvforståelse: Mer enn 80 prosent av lesbiske og 60 prosent av homofile har praktisert heterosex. Noen av disse er uten tvil genuint bifile. Imidlertid antyder data at det i denne kategorien befinner seg mange kvinner og menn som ikke evner å håndtere eller å forholde seg til sitt kjærlighetsliv. Representative data viser eksempelvis at lesbiske/bifile tenåringer befinner seg på toppen av abortstatistikken i USA: 12 prosent av sammekjønnsseksuelle tenåringsjenter har tatt abort én gang mot 5 prosent av selvidentifiserte heterofile. 24 prosent lesbiske/bifile tenåringer oppgir at de har tatt abort mer enn to ganger, mot 10 prosent av heterofile tenåringsjenter (Saewyc, 1999).

\section{Homofil orientering og entydig seksuell praksis beskytter}

I et forebyggende perspektiv er det verdt å merke seg at flere av de nye representative studiene gir klare indikasjoner på at entydig seksuell legning og entydig seksuell praksis virker beskyttende med hensyn til selvmords- og annen risikoatferd, som misbruk av alkohol og narkotiske stoffer og hiv/aids (Pathela et al., 2006; Burgard et al., 2005; Mills et al., 2004; Moseng, 2005; Russel et al., 2001, 2002). Mills et al. (2004) finner at menn som har sex med menn og som ikke forstår seg selv som homofile, bifile eller skeive etc. er overrepresentert i gruppen som var plaget av angst og depresjoner, uavhengig av hvorvidt de var åpne om sin homoseksuelle praksis eller ikke. Pathela et al. (2006) dokumenterer den samme tendens mht. sikrere sexatferd blant menn som har sex med menn: Menn som forstår seg selv som entydig homofile, er den kategorien blant menn som har sex med menn, som har minst risikosex i USA. Liknende funn mht. psykisk helse framgår av Russel et al. (2001, 2002). A debutere tidlig homoseksuelt (før 16 år) er en risikofaktor, men slike og liknende studier dokumenterer også sammenhenger mellom det å debutere sent og det å være plaget av psykiske vansker eller det å fors $\varnothing$ ke å ta sitt eget liv. Såkalte late bloommers har ofte levd heterofilt før de startet opp sine sammekjønnselskende liv. I denne gruppen er lesbiske kvinner klart overrepresentert, noe som utvilsomt er en av forklaringene på at det er eldre lesbiske kvinner som strever mest med helseproblemer i den svenske helseunders $\varnothing$ kelsen, og ikke menn (Roth et al., 2005).

Sammekjønnsseksuelles psykiske helse og suicidatferd synes altså å variere med seksuell livsform. Faktisk synes mye av skjevfordelingen av helse i forhold til den heterofile majoritetsbefolkningen å forsvinne hvis man kontrollerer for hvorvidt kvinner og menn som forelsker seg i personer av samme kjønn, har hatt heterosex eller ikke. I NOVAs unders $\varnothing$ kelse Levekår og livskvalitet blant lesbiske kvinner og homofile menn fra 1999 ble respondentene spurt i detalj om sin psykiske helsetilstand. Når det gjelder ulike psykiske helsedimensjoner, kan det i NOVA 1999 ikke påvises sterke sammenhenger mellom psykisk velbefinnende og seksuell identitet eller seksuell praksis. Derimot når det gjelder selvmordsfors $\varnothing \mathrm{k}$, finner man at sammekjønnselskende kvinner og menn som har praktisert heteroseksualitet er klart overrepresentert. Dette gjelder særlig kvinnene. På samme måte som i Burgard et als. (2005) representative studie fra USA viser norske data en klar skjevfordeling i helse sammekjønnsseksuelle kvinner i mellom. Blant sammekjønnsseksuelle kvinner som har hatt sex med menn, er det dobbelt så mange som har fors $\varnothing \mathrm{kt}$ å ta sitt eget liv enn blant kvinnene som kun har forelsket seg i eller har hatt sex med kvinner. Lesbiske kvinner som kun har hatt sex med kvinner har faktisk like god psykisk helse som heterofile: Kun 11 prosent oppgir å ha fors $\varnothing \mathrm{kt}$ å ta sitt eget liv (den samme andelen som blant heterofile kvinner). 


\section{Konvensjonelle risikofaktorer}

Innenfor konvensjonell selvmordsforskning regnes svake sosiale nettverk, ved siden av tunge psykiske lidelser og høyfrekvent alkoholbruk, som en viktig utløsende faktor ved selvmord og selvmordsfors $\varnothing$ k. Slik er det også blant lesbiske, bifile og homofile. Disse vil - med unntak for tunge psykiske lidelser - bli diskutert nedenfor.

Noe av overrepresentasjonen av selvmordsfors $\varnothing \mathrm{k}$ blant lesbiske og homofile skyldes mangel på sosial st $\varnothing$ tte eller ekskludering/utst $\varnothing$ ting fra sosiale nettverk: ofte alvorlig svikt i viktige sosiale nettverk, som eksempelvis på skole/arbeidsplassen eller i den nærmeste vennskapskretsen eller i familien (Bildt, 2004; Moseng, 2005b). I en studie av godt voksne og eldre (50 - 75 år) lesbiske og biseksuelle kvinners helse oppgir sammekjønnsseksuelle å mangle sosial st $\varnothing$ tte samt ha en dårlig psykisk helse (Valanis et al., 2000). Dette skjer til tross for at eldre sammekjønnsseksuelle kvinner har betydelig høyere sosio $\varnothing$ konomisk status enn godt voksne og eldre kvinner som utelukkende har levd heteroseksuelt. I den svenske helseunders $\varnothing$ kelsen utmerker godt voksne lesbiske kvinner seg ved å være lite fysisk aktive, de er engstelige for å gå ut og er blant de svensker som plages mest av fysisk sykdom og manglende velvære (Roth et al., 2005). Fire av ti lever sosialt isolert, og tre av ti savner emosjonell og praktisk st $\varnothing$ tte. Ikke overraskende er det således lesbiske og homofile som lever i etablerte sammekjønnsseksuelle liv - det vil si oppgir at de er i et fast forhold, lever i samboerskap eller i partnerskap - som rapporterer om best livssituasjon (Mills et al., 2004; Hegna et al., 1999, kap. 6). Det er sammekjønnsseksuelle kvinner og menn som er enslige eller lever ufrivillig i sølibat som er blant dem som strever mest med psykiske og rusrelaterte vansker.

Skjevfordelingen av psykisk helse må også forstås på bakgrunn av rusproblematikk (Russel \& Joyner, 2001). Sammekjønnsseksuelle kvinner og menn er storforbrukere av rusmidler (Burgard et al., 2005; Case et al., 2004; Cochran et al., 2000, 2004; Cochran \& Mays, 2000; Cochran \& Cauce, 2006; DuRant \& Krowchuck, 1998; Faulkner \& Cranston,

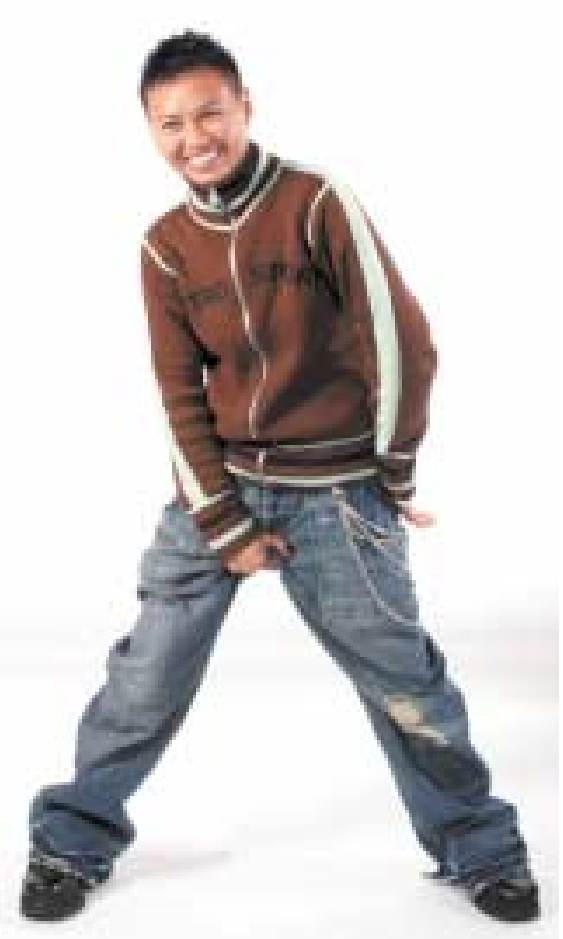

Foto: (c) Lill-Ann Chepstow-Lusty/Oda/BONO 2007 1998; Fergusson, 1999; Garofalo et al., 1998, 1999; Gilman et al., 2001; Gruskin et al., 2001; Hegna et al., 1999; Helmersson, 1996; MacKirnan \& Peterson, 1989; Moseng, 2005; Ridner et al., 2006; Robin et al., 2002; Sandfort et al., 2001; Smith et al., 1999). Likevel er de usynlige i rusog forskningsfeltet, særlig kvinner som har sex med kvinner. For heteroseksuelle kvinner og menn er rusbruken som regel livsfasebetinget: Det å ruse seg ofte og mye eller røyke en hasjsigarett nå og da, hører så og si til det å være tenåring eller ung voksen. Når heterofile kvinner og menn har passert de tredve, går rusbruken drastisk ned. Dette handler blant annet om etablering og institusjonalisering av kjærlighetslivet og det å få barn, samt det å innordne seg arbeidslivet og dets mange krav. Også blant lesbiske, biseksuelle og homofile er det vanlig at rusbruken reduseres betydelig når man har passert voksenlivets terskel. Det er imidlertid oppsiktvekkende mange som fortsetter å være storforbrukere av rusmidler som alkohol og narkotiske stoffer livet ut. Et betydelig mindretall lever i et slags permanent utenforskap. Majoritetssamfunnets normer for "voksen" rusatferd synes aldri å få samme gjennomslagskraft som blant heteroseksuelle kvinner og menn. Et annet problem er at foreliggende forskning antyder at miljøtilh $\varnothing$ righet ikke beskytter, men utgjør en risikofaktor blant lesbiske og homofile. Mye tyder på at de lesbisk/ homofile miljøene ofte er preget av en særegen ruskultur, som antakeligvis har dype historiske røtter.

\section{Sammekjønnsseksuelle kvinner - en} særlig sårbar gruppe?

Anlegger man heterofile kvinner som målestokk, framstår sammekjønnsseksuelle kvinner som en utsatt gruppe mht. bruk av alkohol og narkotiske stoffer. Samlet sett er alkohol-, hasj- og partidopbruken (ghb, ecstasy, amfetamin etc.) foruroligende høy. Sårbarheten antar enda st $\varnothing$ rre dimensjoner når sammenlikningsgrunnlaget er heterofile eller homofile menn. Som kjent er kvinner flest moderate forbrukere av rusmidler. Unntaket er sammekjønnsseksuelle kvinner. Representative befolkningsbaserte data antyder at andelen som ruser seg på alkohol og narkotika, er atskillig st $\varnothing$ rre sammenliknet med heterofile menn. Nyere forskning antyder dessuten at lesbiske og biseksuelle kvinners storforbruk i noen henseender - dette gjelder særlig alkohol og lettere narkotiske stoffer som hasj etc. - er på høyde med eller st $\varnothing$ rre enn storforbruket til homofile menn. Noen ganger befinner de seg på den absolutte rustoppen (Moseng, 2005; Roth et al., 2005; Moseng, 2007).

Sammekjønnsseksuelle kvinners sårbarhet mht. rusmidler handler dels om mengden de konsumerer, men vel så mye om komorbiditet. Selv når inntaket er lavt, synes de negative helsemessige konsekvensene av å ruse seg på alkohol og narkotika å være langt mer omfattende enn blant sammekjønnsseksuelle menn. Fysiologisk sett tåler kvinnekroppen mindre belastninger relatert til rus enn mannskroppen. Det synes også som om kvinner psykososialt sett håndterer rusbelastninger langt dårligere enn menn. Sammenlikner man sammekjønnsseksuelt praktiserende kvinner og menn, er det en betydelig st $\varnothing$ rre andel blant kvinnene som rapporterer at de er plaget av rusrelaterte vansker: Drikkingen går ut over den psykiske og somatiske helsen, de er blitt involvert $i$ alvorlige voldsepisoder etc. 


\section{Konklusjon og anbefalinger}

En ny generasjon med statlige represetative helseunders $\varnothing$ kelser, som inkluderer spørsmål om seksuell orientering, dokumenterer at sammekjønnsseksuelle kvinner og menn er overrepresentert mht. psykisk uhelse, rusmisbruk og selvmordsatferd. Samtidig synes den sammekjønnsseksuelle kjærlighets- og samlivsminoriteten å være oversett og underprioritert både av politikkutformere og behandlingsapparatet. Dette gjelder særlig for kvinnene. Fra et helseforebyggende perspektiv er det et problem at noen sammekjønnsseksuelle velger å skjule eller å underkommunisere sin seksuelle orientering når de er i behandling for eksempelvis psykiske vansker eller et rusproblem. Like problematisk er det at det norske rus- og selvmordsforebyggende arbeidet ikke forholder seg til skjevfordelingsproblematikk, og at sammekjønnsseksuelle behandles som om de var heteroseksuelle kvinner og menn. Da tar man ikke hensyn til de risikofaktorer og beskyttende faktorer som er særegne for nettopp sammekjønnsseksuelle som befolkningsminoritet. Når lesbiske og homofile er plaget av selvmordstanker eller fors $\emptyset$ ker å ta sitt eget liv, er selvsagt ikke alltid problemene relatert til seksuell orientering. Selvmordsfors $\varnothing$ kene kan være "legningsnøytrale" i det de kan være motivert av allmennmenneskelige kriser; som tap av jobb, alvorlig sykdom, tap av viktige familiemedlemmer etc.

Noen vil kanskje innvende at spesialbehandling av sammekjønnsseksuelle derfor ikke er nødvendig. Psykiske vansker og selvmordsatferd blant sammekjønnsseksuelle kan imidlertid ha en direkte sammenheng med nettopp deres liv som sammekjønnsseksuelle. Da er det en helserisiko at norsk helsepersonell ikke per i dag forholder seg målbevisst og strategisk til denne type ikke-heteroseksuell problematikk.

Ofte er det psykiske stresset som sammekjønnsseksuelle opplever, forårsaket av negativ forskjellsbehandling (mobbing, trakasserier, vold), internalisert homofobi, og tilhørende skam- og identitetsproblematikk. En særlig sårbar gruppe er kvinner og menn som forelsker seg i personer av samme kjønn, men som opplever det som mindre verdifullt å leve et sammekjønnsseksuelt kjærlighetsliv. I denne gruppen finner man en overrepresentasjon av selvdestruktiv atferd, f.eks. sammekjønnselskende som har mye og usikker heterosex, misbruker rusmidler etc. Noen av disse gifter seg og kommer seint ut som lesbiske og homofile (såkalte late bloomers) .

I et forebyggingsperspektiv er det således viktig at helsepersonell har forståelse for at psykiske vansker og selvmordsatferd blant sammekjønnsseksuelle handler om mer enn homofile menn og tenåringer $i$ den såkalte komme-ut-fasen. Blant kvinner og voksne sammekjønnsseksuelle er det også en overrepresentasjon av de som kan streve tungt. Disse er gjerne eksperter i å skjule sin seksuelle orientering og lever ofte dobbeltliv. Dette er en pasientgruppe som man må ha et trenet фye for å se.

Makrososiologisk handler helseforebygging blant sammekjønnsseksuelle om politiske grep og endringer av tunge institusjonelle og samfunnsstrukturelle føringer som positivt forskjellsbehandler den heteroseksuelle majoritetsbefolkningen. Dette er et langsiktig prosjekt. På kort sikt handler helseforebygging blant sammekjønnsseksuelle om noe så enkelt som at norske helsemyndigheter og helsepersonell må lære seg å ta minoritetshelseproblematikk på alvor. Leger, terapeuter, sykepleiere må evne å se sine homofile pasientene (knapt to av ti homofile/ lesbiske oppgir at de er åpne i en behandlingssituasjon). Strever ungdom og tenåringer med psykiske vansker eller rusmiddelproblematikk uten at disse kan forankres i velkjente risikofaktorer som tap av sosiale nettverk, rus etc., b $\varnothing \mathbf{r}$ spørsmålet automatisk stilles om hvorvidt helseproblemene kan ha sammenheng med en ikke-heteroseksuell livsform eller orientering. Helsepersonell må også være seg bevisst at en entydig seksuell orientering er en beskyttende faktor mht. rusmisbruk og psykisk helse, det være seg blant heteroseksuelle som blant homoseksuelle kvinner og menn. Således er lesbiske og homofile med en tidlig avklart seksuell identitet og som aldri har hatt heterosex, sjelden plaget av psykiske vansker og selvmordsatferd.
For å motarbeide skam og identitetsproblematikk blant unge er det viktig at betydningsfulle voksne, som foreldre, lærere, leger, sykepleiere og helses østre på skolen, signaliserer nøytralitet mht. valg av kjærlighets- og samlivsform. Ungdommer og tenåringer flest håndterer det å være annerledes, men det er viktig at voksne gir tydelig beskjed om at det å ha et sammekjønnsseksuelt kjærlighetsliv IKKE representerer en mindreverdig livsform eller et dramatisk brudd med hvordan nordmenn flest lever sine liv. Med et slikt enkelt grep kan man forebygge noe av den skam og de negative selvbilder som synes å være drivkraften i mye av den selvdestruktive atferden blant sammekjønnsseksuelle kvinner og menn.

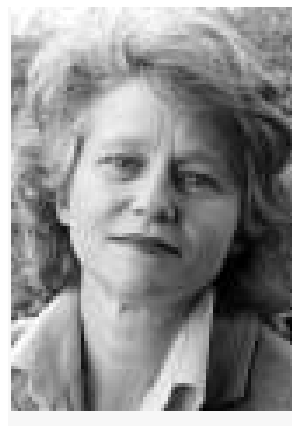

B era U Istein M oseng er doktorgradsstipendiat ved NOVA (Norsk institutt for forskning om oppvekst, velferd og aldring). Blant hennes forskningsarbeider er studier av lesbisk historie, av helse og livsvilkår blant lesbiske kvinner og

homofile menn, alkohol- og narkotikabruk blant befolkningsminoriteter og nordmenns holdninger til ikke-vestlige innvandrere.

\section{Referanser}

Bagley, Cristopher \& Tremblay, Pierre (1997): Suicidal Behaviours in H omosexual and B isexual males. Crisis, 18: 24-34 Bildt, Carina (2004): Facmedlemmars uppfatningar om diskriminering på grund av sexuell läggning på arbetsplatsen. Arbetslivsinstitutet, rapport $\mathrm{nr}$ 2004:10

Bontempo, D.E. \& D'Augelli A.R. (2002): E ffects of atschool victimization and sexual orientation on lesbian, gay, or bisexual youths' health risk behavior. Journal of Adolescent Health, 30(5): 364-374

Burgard, S. A.; Cochran, Susan D. \& Mays, Vickie M. (2005) A Icohol and tobacco use patterns among heterosexually and homosexually experienced C alifornian women. Drug and Alcohol Dependence, 77(1): 61-70

Case, P.; Austin, S.B.; Hunter, D.J.; Manson, J.E.; Malspeis, S.; Willett, W.C. \& Spiegelman, D. (2004): Sexual orientation, health risk factors, and physical functioning in the N urses' H ealth Study II. Journal of Women's Health, 13(9):1033-1047

Cochran, Susan D. \& Mays, Vickie M. (2000): R elation between Psychiatric Syndromes and B ehaviourally D efined Sexual O rientation in a Sample of the U S Population. American Journal of Epidemiology, 151(5): 516-523

Cochran, Susan D. \& Mays, Vickie M. (2000b): Lifetime prevalence of suicide symptoms and affective disorders among men reporting same-sex sexual partners: results from N H A N ES III. American Journal of Public Health, 90(4): 573-578 
Cochran, Susan D. (2001): E merging issues in research on lesbian's and gay men's mental health: D oes sexual orientation really matter? American Psychologist, 56(11): 931-947

Cochran, Susan D., Keenan, Colleen; Schober, Christine \& Mays, Vickie M. (2000): Estimates of A Icohol U se and Clinical Treatment $\mathrm{N}$ eeds A mong $\mathrm{H}$ omosexually A ctive Men and Women in the U .S. Population. Journal of Consulting and Clinical Psychology, 68(6): 1062-1071

Cochran, Susan D.; Mays, Vickie M. \& Sullivan, J. Gree (2003): Prevalence of mental disorders, psychological distress, and mental health services use among lesbian, gay, and bi-sexual adults in the $U$ nited States. Journal of Consul ting and Clinical Psychology, 71(1): 53-61

Cochran, Susan D.; Ackerman, D; Mays, Vickie M \& Ross, M.W (2004): Prevalence of non-medical drug use and dependence among homosexually active men and women in the U S population. Addiction, 99(8): 989-998

Cochran, B.N. \& Cauce, A.M. (2006): Characteristics of lesbian, gay, bisexual, and transgender individuals entering substance abuse treatment. Journal of Substance Abuse Treatment, 30(2): 135-146

Corliss, Heather L.; Cochran, Susan D. \& Mays, Vickie M (2002): R eports of paretal maltreatment during childhood in a U nited States population-based survey of homosexual, bisexual, and heterosexual adults. Child Abuse \& Neglect, 26:1165-1178

Corliss, H.L; Grella, C.E; Mays, V.M. \& Cochran, SD. (2006) D rug use, drug severity, and help-seeking behaviors of lesbian and bisexual women. Journal of Women's Health, 15(5): $556-568$

Degenhardt, L (2005): D rug use and risk behaviour among regular ecstasy users: D oes sexuality make a difference? Culture Health Sexuality, 7(6): 599-614

Diamant, Allison L.; Wold, Cheryl; Spritzer, Karen \& Gelberg, Lillian (2000): $\mathbf{H}$ ealth behaviors, health status, and access to and use of health care: a population-based study of lesbian, bisexual, and heterosexual women. Archives of Family Medicine, 9(10): 1043-1051

Drabble, L.; Midanik, L.T. \& Trocki, K. (2005): R eports of alcohol consumption and alcohol-related problems among homosexual, bisexual and heterosexual respondents: results from the $\mathbf{2 0 0 0} \mathbf{N}$ ational A Icohol Survey. Journal of Studies on Alcohol, 66(1): 111-120

DuRant, R. H. \& Krowchuck D. P. (1998): Victimization, $U$ se of Violence and D rug U se at School among Male A dolescents who engage in Same-Sex Sexual B ehaviour. Journal of Pediatrics, 132: 113-118

Faulkner, Anne H. \& Cranston, Kevin (1998): C orrelates of Same-Sex B ehaviour in an $R$ andom Sample of M assachusetts H igh School Students. American Journal of Public Health, 88: 262-266

Fergusson, David M.; Harwood, John L. \& Beautrais, Annette L. (1999): Is Sexual O rientation R elated to M ental H ealth Problems and Suicidality in Young People? Archives of General Psychiatry, 56: 876-880

Garofalo, R.; Wolf, C.; Kessel, S.; Palfrey J. \& DuRant, R. H. (1998): T he A ssociation between H ealth R isk Behavioor and R isk of Suicide among a Schoolbased Sample of A dolescents. Pediatrics, 101: 895-902

Garofalo, R.; Wolf, C.; Wissow, L. S.; Woods, E. R. \& Goodman, E. (1999): Sexual O rientation and R isk of Suicide A ttempts among a R epresentative Sample of Youth. Archives of Pediatrics and Adolescent Medicine, 153: 487-493 Gilman, Stephen E.; Cochran, Susan S.; Mays, Vickie M.; Hughes, Michael; Ostrow, Davis \& Kessler, Ronald C. (2001): R isk of Psychiatric D isorders A mong Individuals R eporting Same-Sex Sexual Partners in the $\mathbf{N}$ ational Comorbidity Survey. American Journal of Public Health, 91(6): 933-939 Gruskin, Elisabeth P.; Hart, Stacey; Hordon, Nancy \& Ackerson, Lynn (2001): Patterns of Cigarette Smoking and A Icohol $U$ se A mong Lesbians and B isexual W omen Enrolled in a $\mathrm{L}$ arge $\mathrm{H}$ ealth $\mathrm{M}$ aintenance $\mathrm{O}$ rganization. American Journal of Public Health, 91(6): 976-979

Halpern, C.T.; Young, M.L.; Waller, M.W.; Martin, S.L. \& Kupper, L.L. (2004): Prevalence of partner violence in samesex romantic and sexual relationships in a national sample of adolescents. Journal of Adolescent Health, 35(2): 124-31
Hegna, Kristinn; Kristiansen, Hans W. og Moseng, Bera Ulstein (1999): Levekår og livskvalitet blant lesbiske kvinner og homofile menn. NOVA-rapport 1/99. Norsk institutt for forskning om oppvekst, velferd og aldring, Oslo

Hegna, Kristinn (2007): H omo? B etydningen av seksuell erfaring, tiltrekning og identitet for selvmordsforsøk og rus middelbruk. En sosiologisk studie. NOVA-rapport 1/07. Norsk institutt for forskning om oppvekst, velferd og aldring, Oslo Helmersson Bergmark, Karin (1996): Lesbiska kvinnors drikkande. Lesbisk hälsa. Seminarium den 11 december 1996. Riksförbundet för sexuellt likaberättigande (RFSL) Herrell, Richard; Goldberg, Jack; True, William R.; Ramakrishnan, Visvanathan; Lyons, Michael; Eisen, Seth \& Tsuang, Ming T. (1999): Sexual O rientation and Suicidality. A C o Twin C ontrol Study in A dult M en. Archives of General Psychiatry, 56: 867-874

Ljunggren, Gunilla; Fredriksson, Kerstin; Greijer, Åsa \& Rafstedt, Marie-Louise Jädert (2003): A rbetsvillkor och utsatthet. En studie genomförd som ett led $i$ arbetet att motverka diskriminering eller kränkande särbehandling beroende på sexuell lägning. Statistiska, cenralbyrån, Stockholm Mays, Vickie M. \& Cochran, Susan D. (2001): Mental health correlates of perceived discrimination among lesbian, gay, and bisexual adults in the $\mathbf{U}$ nited States. American Journa of Public Health, 91(11): 1869-1876

McKirnan, D. \& Peterson, P. L. (1989): A Icohol and D rug abuse among homosexual men and women: Epidemiology and Population characteristics. Addictive behaviors, 14 $545-553$

Mills, Thomas C; Paul, Jay; Stall, Ron; Pollack, Lance Canchola, Jesse; Chang, Y. Jason; Moskowitz, Judith T .\& Catania, Jodeph A. (2004): D istress and depression in men who have sex with men: the U rban Men's H ealth Study. Am J Psychiatry, 161(2): 278-85

Moseng, Bera Ulstein (2003): Lesbiske og homofile med innvandrerbakgrunn - en pilotundersøkelse. NOVA-rappor $14 / 03$. Norsk institutt for forskning om oppvekst, velferd og aldring, Oslo

Moseng, Bera Ulstein (2005): Skeive dager 2003 - en rusundersøkelse. NOVA-rapport $3 / 05$. Norsk institutt for forskning om oppvekst, velferd og aldring, Oslo

Moseng, Bera Ulstein (2005b): Lesbiske og homofile arbeidstakere- en pilotundersøkelse. NOVA-skriftserie 3/05. Norsk institutt for forskning om oppvekst, velferd og aldring, Oslo Moseng, Bera Ulstein (2007 in press): Vold mot lesbisk og homofil ungdom. En undersøkelse av omfang, risiko og beskyttelse. U ng i 0 slo 2006. NOVA-rapport xx/07. Norsk institutt for forskning om oppvekst, velferd og aldring, Oslo Paul, Jay P.; Catania, Joseph; Pollack, Lance; Moskowitz, Judith; Canchola, Jesse; Mills, Thomas; Binson, Diane \& Stall, Ron (2002): Suicide attempts among gay and bisexua men: lifetime prevalence and antecedents. American Journa of Public Health, 92 (8): 1338-45

Pathela, Preeti; Haja, Anjum; Schillinger, Julia; Blank, Susan Sell, Randall \& Mostashari , Farzad (2006): D iscordance between Sexual B ehavior and Self-R eported Sexual Identity: A Population-Based Survey of N ew York City Men. Annals of Internal Medicine, 145(6): 416-425

Remafedi, Gary; French, Simone; Story, Mary; Resnick,

Michael \& Blum, Robert (1998): T he R elationship B etween Suicide $\mathbf{R}$ isk and Sexual $O$ rientation: R esults of a Population-B ased Study. American Journal of Public Health, 88 57-60

Remafedi, Gary (1999): Sexual O rientation and Youth Suicide. Journal of the American Medical Association, 282: 1291-1292 Remafedi, Gary (1999b): Suicide and sexual orientation: nearing the end of controversy? Archives of General Psychiatry, 56(10), 885-886

Resnick, M. D.; Bearman, P. S.; Blum, R. W.; Bauman, K. E.; Harris, K. M.; Jones, J., Tabor, J.; Behring, T.; Sieving, R. E. Shew, M.; Ireland, M.; Bearinger, L. H. \& Uldry, J. R. (1997) Protecting adolescents from harm; Findings from the $\mathbf{N}$ ational Longitudinal Study on A dolescent $\mathbf{H}$ ealth. Journa of the American Medical Association, 278 (10): 823-832

Ridner, Lee S.; Frost, Karen \& LaJoie, A. Scott (2006):

$H$ ealth Information and R isk B ehaviors among Lesbian,
G ay, and B isexual C ollege Students. Journal of the American Academy of Nurse Practioners, 18: 374-378

Robin, Leah; Brener, Nancy D.; Donahue, Shaun F.; Hack Tim; Hale, Kelly \& Goodenow, Carol (2002): A ssociation B etween $\mathrm{H}$ ealth $\mathrm{R}$ isk B ehaviors and 0 pposite-, Same-, and Both-Sex Sexual Partners in R epresentative Samples of Vermont and M assachusetts H igh School Students. Archives of Pediatrics and Adolescent Medicine, 156: 349 355

Roth, Niklas; Boström, Gunnel og Nykvist, Karin (2005): H älsa på lika V illkor? - hälsa och livsvillkor blant hbtpersoner. Statens Folkhälsoinstitut, Stocholm

Russel, Stephen T.; Seif, H. \& Truong, N. (2001): School outcomes of sexual minority youth in the $U$ nated States: evidence from a national study. Journal of Adolescence, 24(1) 111-127

Russell, Stephen T; Franz, BT \& Driscoll, AK (2001b): Same sex romantic attraction and experiences of violence in adolescence. American Journal of Public Health, 91(6): 903-906 Russell, Stephen T. and Joyner, Kara (2001): A dolescent Sexual 0 rientation and Suicide R isk: Evidence From a N ational Study. American Journal of Public Health, 91(8) 1276-1281

Russel, Stephen T.; Driscol, A. K. \& Truong, N. (2002): A dolescent same-sex romantic attractions and relationships: implications for substance use and abuse. American Journa of Public Health, 92(2): 198-202

Russel, Stephen T. (2003): Sexual minority youth and suicide risk. American Behavioral Scientist, 46: 1241-1257

Saewyc, E.M.; Bearinger, L.H.; Blum, R.W. \& Resnick, M.D. (1999): Sexual intercourse, abuse and pregnancy among adolescent women: does sexual orientation make a difference? Fammily Planning Perspectives, 31(3): 127-131 Saewyc, E.M.; Skay, C.L.; Pettingell, S.L.; Reis, E.A.; Bearinger, L.; Resnick, M.; Murphy, A. \& Combs, L. (2006) $H$ azards of stigma: the sexual and physical abuse of gay, lesbian, and bisexual adolescents in the $U$ nited States and C anada. Child Welfare, 85(2): 195-213

Sandfort, Theo G. M.; de Graaf, Ron; Bijl, Rob V.; Schnabel, Paul (2001): Same-sex Sexual B ehavior and Psychiatric D isorders. Archives of General Psychiatry, 58: 85-91

Sandfort, Theo G. M.; Bakker, F.; Schellevis, F.G. \& Van wesenbeeck, I. (2006): Sexual orientation and mental and physical health status: findings from a dutch population survey. American Journal of Public Health, 96(6): 1119-1125 Scheer, S.; Peterson I.; Page-Shafer, K.; Delgado, V.; Gleghorn, A.; Ruiz, J.; Molitor, F.; McFarland, W. \& Klausner, J. (2002) Sexual and drug use behavior among women who have sex with both women and men: R esults of a population-based survey. American Journal of Public Health, 92 (7): 1110-1112 Scheer, Susan; Parks, Cheryl A.; McFarland, Willi; Shafer, Kimberly Page; Delgado, Viva; Ruiz, Juan; Molitor, Fred \& Klausner, Jeffrey D (2003): Self-R eported Sexual Identity, Sexual B ehaviors and $H$ ealth R isks: Examples from a Population-B ased Survey of Young W omen. Journal of Lesbian Studies, 7 (1): 69-83

Skegg, K. S.;Nada-Raja, Dickson, N.; Paul, C. \& Williams, S. (2003): Sexual O rientation and Self-H arm in Men and W omen. American Journal of Psychiatry, 160(3): 541-546 Smith, Anthony M. A.; Lindsay, Jo; Rosenthal \& Doreen A. (1999): Same-Sex A ttraction, D rug Injection and Binge D rinking among $A$ ustralian A dolescents. Australian and New Zealand Journal of Public Health, 23 (6): 643-646

Trocki, K.F.; Drabble, L. \& Midanik, L. (2005): U se of heavier drinking contexts among heterosexuals, homosexuals and bisexuals: results from a $\mathbf{N}$ ational $\mathbf{H}$ ousehold Probability Survey. Journal of Studies on Alcohol, 66(1): 105-110 Valanis, B.G.; Bowen, D.J; Bassford, T.; Whitlock, E.; Charney, P. \& Carter, R.A. (2000): Sexual orientation and health: comparisons in the women's health initiative sample. Archives of Family Medicine, 9(9): 843-53 